\title{
The Nasakom Ideology in the Short Stories of Varia Magazine
}

\author{
$1^{\text {st }}$ Syifa Hanifah \\ Literature Department, Faculty of \\ Humanities \\ Universitas Indonesia \\ Depok, Indonesia \\ syifa.hanifah51@ui.ac.id
}

\author{
$2^{\text {nd }}$ Mamlahatun Buduroh* \\ Literature Department, Faculty of \\ Humanities \\ Universitas Indonesia \\ Depok, Indonesia \\ mamlahatun.buduroh@ui.ac.id
}

\begin{abstract}
The concept of Nasakom was one of the most important pillars of Indonesian president Soekarno's Guided Democracy in 1965. Fundamentally, Nasakom is an attempt to merge three major ideologies: (1) nationalism as an attitude of defense and love for the state, (2) religion as an attitude of trust in God, (3) and communism as the attitude of struggle of the Marhaenist to be free from oppression. In 1960s Indonesia, magazines were one example of printed mass media that spread the concept of Nasakom. The inclusion of Nasakom in magazines also influenced the short stories included. This essay addresses Nasakom through the lens of the characters in three short stories in Varia magazine published in 1965: "Malam Tari Panen Bahagia," "Potret," and "Pergumulan Iman." To support the discussion of this article, the researchers use the characterization analysis method to analyze the literature through the lens of sociology as a reflection of the government's thinking during the Guided Democracy period. This article describes the nationalism, religion, and communism ideologies that go together in everyday life as a manifestation of Nasakom, which is conveyed through the attitudes of the characters in the short story. This research is significant in elucidating the function, role, and position of literature in history as the disseminator of Nasakom in Soekarno's administration in 1965.
\end{abstract} Varia

Keywords—short story, Nasakom, Soekarno, characters,

\section{INTRODUCTION}

Soekarno's Guided Democracy system from 1959-1966 brought a period of conflict to Indonesia. One of the things that aroused controversy at that time was the birth of the term Nasakom, a concept invented by Soekarno in the 1920s. However, its existence only reappeared during the Indonesian revolution against imperialism and neocolonialism in the 1960s. Fundamentally, the concept of Nasakom is the government's attempt to combine three major political ideologies, namely, nationalism, religion, and communism. The presence of communism ideology was then considered a problem.

Although the conception of Nasakom resulted in many polemics, according to the Soekarno's administration, the conception aimed for a harmonious state. Therefore, to disseminate the Nasakom doctrine to the public, the government engaged in a variety of strategies, including printed mass media, namely magazines. At the same time, magazines produce literary work, especially prose in the form of short stories. The presence of Nasakom in a magazine certainly influences the short stories in it.
One of the magazines that stated its support for Soekarno's administration at that time was Varia. This support can be seen in the change in the motto of Varia magazine, whose editorial statement in issue 356 published on April 21, 1965 signaled a transition from colorful entertainment magazine to a magazine that supported the revolution. The closeness between Varia and the government was once again indicated in issue 357 , a week after the announcement of the turnaround of the magazine. On that day, Varia magazine re-published an article showing mutual support between the magazine's editor and the government through an article titled "Djuga Varia Harus Banting Setir" containing a message from the Minister of Communications for Transportation (Coordinating Minister for Transportation) to the magazine to adhere to the government's policy.

The affiliation between Varia and the government makes the short stories in the magazine an interesting subject. Therefore, in this article, the researchers will evaluate Varia and three short stories that were published near the time when the magazine started to establish its affiliation with the government and also best show the concept of Nasakom. The selected short stories are "Malam Tari Panen Bahagia" by K. L. Wimandjaya, "Portret" by Josefi, and "Pergumulan Iman" by Eka Chandra. The depiction of nationalism, religion, and communism in the conception of Nasakom through short stories in Varia magazine is an interesting problem to be studied regarding the relationship between literary works and political events of the 1960s.

Research on the relationship between literature and events of the 1960s has been done before in Indonesia. However, this study has several differences with previous studies. First, the data sources of the short stories in Varia have not been reviewed in previous studies. Second, although there is extant research on literary works and events of the 1960s, there has never been a discussion on the relationship between Nasakom as a whole in literary works. Lastly, in contrast to previous research, this study describes the embodiment of figures in the short story of Varia as a government effort to spread the concept of Nasakom through literary works in the mass media. Thus, this study discusses the relationship between Nasakom and characterization in Varia magazine's short stories in 1965 and aims to elucidate the efficacy of using literature to support government ideologies in the Soekarno administration. 


\section{METHOD}

In this study, the researchers analyzed the data using descriptive analysis methods. The descriptive analysis method is done by describing the facts that are then followed by analysis (Ratna, 2013: 53) [3]. Based on this, in this study, the researchers describe the facts obtained from the research in the form of a description of the attitudes and traits of the characters in the story. Then the researchers' analysis of the interrelationship between Nasakom's three ideologies (nationalism, religion, and communism), and the characterizations in the stories become the research data.

The literary sociology approach is used to support data analysis. Sociology of literature is an objective scientific study of people and society, institutions, and social processes in literary works. In literary sociology, literary works are considered to be the mirror of an era. In connection with this, the task of literary sociology is to connect fictional figures in literary works with historical circumstances and their origins [4]. It is necessary to see the influence of things outside the literary work on the content of literary works. Literary sociology is an approach to literature that utilizes socioculture.

To conduct the research, the researchers carried out several stages. First, the researchers determined the theme and background of the research, namely the relationship between literary works and Nasakom during the Guided Democracy period of 1965 . Then, the researchers conducted a literature review related to the theme and background of the research. After that, the researchers collected research data in the form of short stories from Varia magazine, published in 1965 and several supporting articles related to Nasakom. Based on the data collected, the researchers determined the approach and research method. These methods and approaches became the researchers' foundation for analyzing research data. In conducting the analysis, the writer made the characterization in the short stories tools to describe the Nasakom. In addition, to support the research analysis, theories related to short stories and characterizations are used to complement the research data. Finally, the researchers drew conclusions from the results of the analysis.

\section{RESULTS}

The three short stories discussed in this section are stories of revolution that reflect Nasakom and show that literary works contribute to indoctrinating people in certain ideologies. This clarifies the importance of literature's role, especially short stories, in the mass media during Soekarno's administration in the history of spreading Nasakom. Nasakom is further divided into three ideologies namely, nationalism, religion, and communism. Therefore, in this section the writer will elaborate on the Nasakom ideologies that are illustrated in the three short stories.

\section{A. Nationalism Varia Magazine's Short Stories}

In general, the concept of nationalism in Indonesia has existed since the 1920s. The concept is a discourse to break the boundaries of ethnic differences (Suryadinata, 2010) [5]. This understanding was symbolically supported by Soekarno with human values such as mutual cooperation, solidarity, togetherness, nationalism but not cauvinism [6]. Specifically, the concept of unity or nationalism in Nasakom is a movement based on love; it cannot be separated from the defending attitude toward the state and homeland [7]. According to Silabuan [8], based on Soekarno's thoughts, nationalism was also part of an anti-colonial attitude in the form of everything that was considered to attack and threaten the community.

In the short stories in Varia magazine, the form of nationalism is conveyed through the attitude of the protagonists in the story. In "Malam Tari Panen Bahagia," a nationalist character, Wiman, volunteered to defend the country. Suddenly Lina, a woman who loved Wiman, also volunteered. This story implies that being nationalist is wise and does not look at gender status. Men or women will rise in rank if they are willing to leave the comforts of home to defend the country.

The concept of nationalism in the realization of selfsacrifice is then found in the short story "Potret." In this short story, again nationalism is manifested through the attitude of its protagonist, Muljo. Muljo is a volunteer who participated in military activities. Muljo was willing to leave his girlfriend Ana to defend the country. In this short story, it is hinted that Muljo's sacrifice for the state did not destroy his relationship with his girlfriend but instead strengthened their ties because in the same military service, he met his girlfriend's brother, and this strengthened their relationship.

Based on the two short stories, nationalism requires the perpetrators to sacrifice first before obtaining results. In the first short story, Wiman sacrificed his parents' inheritance and love of Lina for his sister. Wiman's sacrifice was not in vain; because of his sincerity to defend the country, he got the love of Lina, who followed him to volunteer. Similar to the first short story, Muljo's sincerity of leaving his lover to participate in military activities earned him the blessing of his lover's brother who, incidentally, was the captain of the place where he served.

Another story in Varia magazine illustrates the attitude of nationalism in a different way. In "Pergumulan Iman," the attitude of nationalism is manifested through anticolonialism. The colonists in this short story are loan sharks-high-interest debt collectors. A character named Sulastri in this short story succeeded in rejecting the debt collector's offer to be married to a merchant. Even though she is urged to pay the debt, Sulastri prefers to be loyal to her husband rather than doing things that are only material, which is in line with the ideology of nationalism conveyed by Soekarno. According to Soekarno, Indonesian nationalism is different from chauvinism or Western nationalism because it did not trigger conflict. Nationalism under Soekarno is also referred to as the concept of Eastern nationalism. Eastern nationalism is not concerned only with material value like its Western counterpart, which is only concerned with profit and loss, but the principle of morality against invaders who are also spiritual in nature [9].

Debt collectors and merchants in "Pergumulan Iman" are compared to colonists. Sulastri's attitude can be implemented as the true meaning of Soekarno's nationalism, which is against colonialism in all forms of threats and attacks. That Sulastri upholds her dignity even though she is a poor person is a manifestation of the attitude of nationalism against the attitude of imperialism, which does not care about the dignity of human beings. In "Pergumulan Iman" then came the 
character Kartawidjaja, who suddenly became the savior of the life of the Sulastri family by giving money to pay off the debts of Sulastri and her husband Soelaiman. Kartawidjaya is an old friend of Soelaiman who came to return the favor for his kindness in the past.

The character Karta Wijaya represents the attitude of a nationalist: someone willing to serve and improve the lot of the poor and protect the people from oppression and exploitation of the invaders [10]. Debt collectors and merchants can be categorized as capitalists and bourgeois who deserve to be confronted with nationalist attitudes. The bourgeoisie is a level of middle and upper classes that is usually opposed to the common people. Resistance against the capitalists and the bourgeoisie corresponds to the statement of Soekarno in Sjamsuddin [10] that oppression did not only come from foreign nations but came from the nation's capitalists themselves, from the arbitrariness of the bourgeoisie. The capitalist and bourgeois oppressors in question are the wealthy owners of capital and the nobility or the people from the upper-middle class who are usually opposed to the common people [11].

Thus, based on the descriptions above, it can be concluded that, through the nationalist attitudes of the figures in the three short stories of Varia, there are three forms of nationalism that are most prominent. First, there is the form of defending the country by plunging directly into volunteer $r$ work, as described in the short stories "Malam Tari Panen Bahagia" and "Potret." Second, there is Sulastri's opposition to the power of the bourgeoisie, which became the implementation of colonialism and imperialism. Finally, there is the nationalist attitude of improving the lot of the poor, as seen through Kartawidjaya's character. The three short stories also show the element of "suddenness," which signifies that carrying out an attitude of nationalism will lead to unexpected benefits.

\section{B. The Religion Ideology in Varia Magazine's Short Stories}

Fundamentally, humans carry the instinct to have religion from birth [12]. This is evidenced by the existence of the God spot in the human brain. This basic situation then occurs in the subconscious of humans, which, when continuously carrying out certain spiritual activities, will develop into a collective unconscious. Religion, the second ideology in Nasakom, is teaching that regulates the procedures of faith (belief) and personality to God Almighty and rules that relate to the relationship between humans and with humans and their environment. With Nasakom, Soekarno surmised that a country must have God, no matter who that God was; a country without God will experience destruction [9]. Thus, everything related to the relationship to God Almighty is part of the religious ideology in Soekarno's conception of Nasakom.

The concept of religion in the short stories of Varia magazine is depicted through submission to God. The declaration of surrendering self to God is conveyed in several ways. First, it is expressed through prayer, as is often done by Wiman in the short story "Malam Tari Panen Bahagia." Second, it is an expression of guilt from a person to God as Sulastri's statement in "Potret" and Wiman in "Malam Tari Panen Bahagia." Third, it is shared through religious stories, such as those in "Pergumulan Iman" concerning the power of God in providing sustenance to a selfless poor person.
In the theory of religious psychology, submission to God can be categorized as the existence of religion as a cognitive function of a person. As a person's cognitive development, surrendering self to God is a human effort to provide answers that are beyond the limits of the human mind [12]. Religious ideology cannot be separated from the short stories "Pergumulan Iman" and "Malam Tari Panen Bahagia." Both short stories glorify the existence of God through the act of trust and surrender to God Almighty. God in the two short stories is the highest place to depend and the final choice to ask for help. This shows the role of religion in life is very necessary so that humans have a unifying source and do not experience despair

\section{The Communism Ideology in Varia Magazine's Short Stories}

In Nasakom, the ideology of communism is an attempt to replace individual property rights with state property. Communism in Nasakom is Marxism modified by Soekarno. This ideology is non-cooperative, involves mass action, and forms a revolutionary force. This is in line with the opinion of Alfian [13] that communism in Indonesia adopted concepts from Western communism but was supported by traditional principles. In contrast to the original Marxism, the one adopted by Soekarno not only used the power of the proletariat but also included the marhaenist. Unlike the proletariat, the marhaenist in the ideology of communism under Nasakom is a combination of workers, peasants, fishermen, and other poor people [9]. Marhaenist was created by Soekarno as the picture of people's poverty [14].

In the short story "Malam Tari Panen Bahagia," the marhaenist are depicted through peasant figures. Indonesian farmers have the strength of perseverance and firmness. These strengths are the basis of the strength of the mass adherents of communism ideology. The peasants are the political vehicle for the search for communism under the auspices of the Indonesian Communist Party. This is in line with Bari's statement [15] that the step taken by the Communist party in seeking mass support is by recognizing various aspects of peasant life in relation to agrarian issues.

Discussions about farmers cannot be separated from the lessons learned from nature. Based on this, the principle of communism in the short stories re-emerged when Wiman, in "Malam Tari Panen Bahagia," realized the sabotage carried out by Sofjan to take his inheritance. At that time, Wiman traveled to the hill to get eagle eggs, but he did not do it because he found the key to the rice barn that had been passed on to him. It was there that he realized that the key had been stolen by Sofjan because Sofjan's handkerchief was left to bind the key. After that, he returned to the hill and saw the eagle eggs he had taken had hatched. From there he learned from nature that matter is not everything. The spiritual journey that Wiman experienced to become a good person was given by nature. This is in accordance with the ideology of communism; that we have to give everything back to nature.

The depiction of the marhaenist in the portrayal of the labor worker was also realized through the figure of Soelaiman in the short story "Pergumulan Iman." In this short story, Soelaiman is a worker with a small salary who continues to struggle against poverty. In Soekarno's view, the ideology of communism in Nasakom did not create a 
society without God as a higher being. However, it is also not a group that glorifies material substance. The Nasakom in the discussion is the rejection of dependency and excessive admiration for material things. This principle is illustrated in the three short stories in Varia magazine. It can be seen from the traits of the mostly poverty-stricken characters who are still grateful for their situation.

The presence of communism in the short stories can also be related to the overall traits of the characters. In "Potret," communism is depicted through the attitudes of the characters. Unlike the other two short stories, in this short story the characters never even talked about or mentioned the word God. In addition, Muljo, based on the way he described his wealthy friend Toto as being his opposite, is the proletariat or a person from the lower economic class of the society. This is also supported by the daily life of Muljo, who does not use vehicle because he does not own one. His character comes from Blitar and studied in a university in Yogyakarta. These two places become important to show the identity of Muljo's character as a communist because Blitar and Yogya are two of the Communist party bases.

The power of communism illustrated in the short story is supported by the article written by Murani in Varia magazine issue 359 dated March 7, 1965 in an article entitled "Bubarkan Semua Alat jang djadi Antek²nja BPS." The article contained a statement that the press should side with the government for the BPS to be dissolved because it was considered counter-revolutionary by rejecting communism. Then, in the same article, Soekarno announced support for the Indonesian Journalists Association (PWI), which was not an anti-communist group. The interesting thing about the formation of PWI in addition to its alignment with communism is that PWI is also said to side with the marhaenist, signaling the closeness between the two.

Thus, based on the descriptions above, it can be concluded that the ideology of communism in Soekarno's mind was conveyed implicitly in the short stories and strengthened with several supporting articles. The communist characters in the stories are marhaenist who depend on nature, lead simple but happy lives, and reject submission to material things.

\section{CONCLUSION}

Through this research, it can be seen that Nasakom and its three ideologies are incorporated and illustrated through the attitudes and actions of the characters. This suggests that the three ideologies can go hand in hand without reaping conflict, just as Soekarno intended with the creation of Nasakom. The three short stories in the magazine in this study can be used as the tools to disseminate the ideology of Nasakom during Soekarno's Guided Democracy in 1965.

Considering there are still many short stories or other literary works that have not been studied in terms of their influence on the political situation of Indonesia under Guided Democracy, this research is a contribution to the topic of literary research in the mass media in 1965. This research is expected to contribute to the study of the role of literature in the history of Indonesia and can be the first step to examine existing problems more deeply and with various other perspectives, especially regarding Nasakom's implementation and its relationship with literary works in
Indonesian mass media in the past. We hope this research can be a reference for future studies and be perfected by subsequent researchers.

\section{Closing}

To close, I would like to thank all parties involved in this research. I express my gratitude to the H.B Jassin Literature Documentation Center for providing the data source in the form of Varia magazine and a convenient place for me to sort out my research material. Thank you to the writers and researchers of the past whose names I cannot mention one by one who became my reference source in conducting research. Thank you to FIB UI, especially the committee of the Inusharts 4.0 program, who has given me the opportunity to write this article.

\section{REFERENCES}

[1] Imtihani, Inung. (2013). Cerpen-Cerpen Pemenang Hadiah Majalah Sastra 1961-1963 Di Tengah Pertentangan Politik 1960-an (Short Stories Winners of Literature Magazine Prizes 1961-1963 amid Political Conflicts of the 1960s). Thesis. Depok: Universitas Indonesia.

[2] Ratna, Nyoman Kuntha. (2013). Teori, Metode, dan Teknik Penelitian Sastra (Theories, Methods and Techniques of Literary Research). Yogyakarta: Pustaka Pelajar.

[3] Damono, Sapardi Djoko. (1984). Sosiologi Sastra: Sebuah Pengantar Ringkas (Sociology of Literature: A Brief Introduction). Jakarta: Pusat Pembinaan dan Pengembangan Bahasa.

[4] Dewantara, Agustinus Wisnu. (2016). Gotong-Royong Menurut Soekarno Dalam perspektif Aksiologi Max Scheler, Dan Sumbangannya Bagi Nasionalisme Indonesia (Gotong Royong according to Soekarno in the perspective of Max Scheller's axiology and its contribution to Indonesian nationalism). Malang: STFT Widya Sasana.

[5] Widodo, Suwarno. (2011). "Implementasi Bela Negara Untuk Mewujudkan Nasionalisme. (Implementation of Defending the State to Create Nationalism)" Jurnal Civis, Vol. 1, No. 1, January. Semarang.

[6] Silaban, Winner. (2012). "Pemikiran Soekarno Tentang Nasionalisme (Soekarno on Nationalism)" Jurnal Dinamika Politik, Vol.1, No.3, December: 1 -6. Medan: Universitas Sumatera Utara.

[7] Soekarno. (1959). Di Bawah Bendera Revolusi I (Under the Flag of Revolution I). Jakarta: Panitia Penerbit.

[8] Sjamsuddin, Nazaruddin. (1988). Soekarno: Pemikiran Politik dan Kenyataan Praktek (Soekarno: Political Thought and the Reality). Jakarta: Rajawali Pers

[9] Budiwiyanto, Adi, dkk. (2016). Kamus Besar Bahasa Indonesia V (Indonesian Dictionary V). Jakarta: Badan Pengembang dan Pembinaan Bahasa KEMENDIKBUD RI.

[10] Subandi, M. A. (2013). Psikolog Agama dan Kesehatan Mental (Psychologist of Religion and Mental Health). Yogyakarta: Pustaka Pelajar.

[11] Damono, Alfian. (1981). Pemikiran dan Perubahan Politik Indonesia (Indonesian Political Thought and Change). Jakarta: Penerbit PT Gramedia.

[12] Indrakesuma, Roestini Wulan. (1987). Persepsi Soekarno Tentang Marhaen (Sukarno's Perception About Marhaen). Thesis. Depok: Universitas Indonesia.

[13] Bari, Ahmad Fathul. (2008). Strategi Partai Komunis Indonesia Terhadap Petani dan Pengaruhnya di Jawa Timur: 1953-1965 (The Indonesian Communist Party's Strategy towards Farmers and Their Influence in East Java: 1953-1965). Thesis. Depok: Universitas Indonesia.

[14] Damono, Sapardi Djoko. (1999). Politik, Ideologi dan Sastra Hibrida (Politics, Ideology and Hybrid Literature). Jakarta: Pustaka Firdaus.

[15] Dewantara, Agus Wisnu. (2010). Negara Gotong Royong menurut Soekarno (Gotong Royong State according to Soekarno). Theis. Malang: STFT Widya Sasana. 
[16] Dhakidae, Daniel, dkk. (2013). Soekarno membongkar sisi-sisi hidup putra sang fajar (Sukarno dismantled the life aspects of the son of the dawn). Jakarta: Kompas.

[17] Fakih, Farabi. (2014). “Akar-Akar Kanan daripada Nasionalisme Indonesia, Nasionalisme Jawa dalam Konteks Kesejarahannya (Right Roots of Indonesian Nationalism, Javanese Nationalism in Its Historical Context)". Lembaran Sejarah, Vol. 11, No. 1, April: 3749. Yogyakarta: Universitas Gadjah Mada.

[18] Latif, Yudi. (2018). "The Religiosity, Nasionality, and Sociality of Pancasila: Toward Pancasila Trough Soekarno's Way". Journal Studia Islamika Vol. 25, No. 2. 207-247. Jakarta: Universitas Islam Syarif Hidayatullah.

[19] Lin, Hongxuan. (2018). "Sickle as Crescent Islam and Communism in the NetherlandsEast Indie, 1915--1957”. Journal Studia Islamika Vol 25, No. 2. 309-350. Jakarta: Universitas Islam Syarif Hidayatullah

[20] Maryati. (2011). Sajak-Sajak Soe Hok Gie Tahun 1960-1969: Kajian Sosiologi Sastra (Poems of Soe Hok Gie 1960-1969: Study of Sociological Literature). Thesis. Depok: Universitas Indonesia.

[21] Mortimer, Rex. (2011). Indonesian Comunism Under Sukarno. Yogyakarta.

[22] Nurgiyantoro, Burhan. (1998). Teori Pengkajian Fiksi (Theory of Fiction Studies). Yogyakarta: Gadjah Mada.

[23] Pradjoko, Didik. (2009). Peristiwa Sekitar Krisis Nasional Tahun 1965 Sebagai Latar Sosial-Politik Karya Sastra Indonesia Tahun 1966-1974: Kajian Awal Cerpen-Cerpen dalam Majalah Sastra dan Majalah Horison (Events Around the 1965 National Crisis as a Socio-Political Background of Indonesian Literature in 1966-1974: Preliminary Study of Short Stories in Literary and Horizon Magazines). Research Report. Depok: Universitas Indonesia

[24] Pradopo, Rachmat Djoko. (1995). Beberapa Teori Sastra: Metode, Kritik dan Penerapannya (Some Literary Theories: Methods, Criticism and Implementation). Yogyakarta: Pustaka Pelajar.

[25] Ricklefs, M. C. (2008). Sejarah Indonesia Modern 1200-2008 (History of Modern Indonesia 1200-2008). Jakarta: Serambi.

[26] Salmon, Claudine. (1985). Sastra Cina Peranakan Dalam Bahasa Melayu (Peranakan Chinese Literature in Malay). Jakarta: Balai Pustaka.

[27] Sambodja, Asep. (2011). Asep Sambodja Menulis: Tentang Sastra Indonesia dan Pengarang-Pengarang Lekra (Asep Sambodja writes: About Indonesian Literature and Lekra Authors). Bandung: Ultimus.

[28] Soeprapto, R. (2003). Refleksi Reformasi vs Reformasi (Reflections on Reformation vs. Reformation). Jakarta: Taman Pustaka.

[29] Sudjiman, Panuti. (1992). Memahami Cerita Rekaan (Understanding Fiction). Jakarta: Pustaka Jaya.
[30] Sumardjo, Jakob dan Saini. (1991). Apresiasi Kesusastraan (Literary Appreciation). Jakarta: Gramedia Utama.

[31] Suparmo, E. (2009). Strategi Ketenagakerjaan Nasional (National Employment Strategy). Jakarta: Kompas.

[32] Suryadinata, Leo. (2010). Etnis Tionghooa dan Nasionalisme Indonesia (Chinese ethnicity and Indonesian nationalism). Jakarta: Kompas.

[33] Syahdu, Mada Sofa. (2002). "Film dan Politik di Indonesia 1957-64: Hambatan Peredaran Pagar Kawat Berduri dan Anak Perawan di Sarang Penyamun (Films and Politics in Indonesia 1957-64: Barriers to the Distribution of Barbed Wire Fence and Virgin Children in the Robbers' Nest)". Jurnal Wacana, Vol. 4. No.1, April: 84-99. Universitas Indonesia.

[34] Wardhani, Prima Sulistya. (2013). "Membaca Nasionalisme Orang Muda (Reading Nationalism on Young People)". JURNAL STUDI PEMUDA, Vol. 2. No. 2, September: 204-219. Yogyakarta: Universitas Gadjah Mada.

[35] Wellek, Rene dan Austin, Warren. (1989). Teori Kesusastraan (Literary Theory). Jakarta: Gramedia.

[36] Widjaja, A.W. (1985). Masyarakat dan Pemasyarakatan Ideologi Pancasila (Society and Penitentiary of Pancasila Ideology). Bandung: Armico.

[37] Winata, Lingga. (2017). "Nasakom Sebagai Ideologi Negara Tahun 1959-1965 (Nasakom as the State Ideology, 1959-1965)" AVATARA, e-Journal Pendidikan Sejarah Volume 5, No. 3, October: 728-737. Surabaya: UNESA.

\section{DATA SOURCE}

[1] Alfian. Asmara, Andjar, dkk. (1965). "Integrasikan Diri dengan Kondisi Revolusi (Integrate Yourself with the Revolution)". Varia No. 356, April 21. Jakarta: PT Kinta.

[2] "Djuga Varia Harus Banting-Stir (Varia also Should Swerved)". Varia No. 357, April 28. Jakarta: PT Kinta

[3] Chandra, Eka. (1965). "Pergumulan Iman (The Struggle of Faith)". Varia No. 365, 14 April. Jakarta: PT Kinta.

[4] Josefi. (1965). "Potret (Portrait)". Varia No. 361, 17 March. Jakarta: PT Kinta.

[5] Litohoe, Wimandjaya K. (1965). "Malam Tari Panen Bahagia (Harvest Dance Night)". Varia No. 360, 10 March. Jakarta: PT Kinta.

[6] Murani, Asnaloi. (1965). "Bubarkan Semua Alat jang djadi Antek ${ }^{2}$ nya BPS (Disperse Everything that related to BPS)". Varia No. 359, March 7. Jakarta: PT Kinta 